\title{
Molecular Basis of an Autoantibody-associated Restriction Fragment Length Polymorphism that Confers Susceptibility to Autoimmune Diseases
}

\author{
Tsaiwei Olee, Pei-Ming Yang, Katherine A. Siminovitch,“ Nancy J. Olsen, ${ }^{\dagger}$ Jan Hillson, ${ }^{\star}$ \\ Jennifer Wu, Franklin Kozin,' Dennis A. Carson, and Pojen P. Chen \\ Department of Medicine and the Sam and Rose Stein Institute for Research on Aging, University of California, San Diego, La Jolla, \\ California 92093; *Department of Medicine, University of Toronto, Toronto, Ontario M5T 2S8, Canada; ${ }^{\dagger}$ Department of Medicine, \\ Vanderbilt University, Nashville, Tennessee 37232; ${ }^{\ddagger}$ Department of Medicine, University of Washington, Seattle, \\ Washington 98195; ${ }^{\$}$ Department of Molecular and Experimental Medicine, Research Institute of Scripps Clinic, \\ 10666 North Torrey Pines Road, La Jolla, California 92037
}

\begin{abstract}
Recently, combined serological and molecular studies of autoantibodies have revealed that these antibodies play an important role in the normal function of the immune system and in the development of the $B$ cell repertoire. Accordingly, we hypothesized that a homozygous deletion of a critical autoantibody-associated Ig variable (V) gene may alter the immune system and thus predispose the host to autoimmune disorders. Initial experiments revealed several restriction fragment length polymorphisms (RFLP) of the Humhv3005 gene, that is likely to encode heavy chains of rheumatoid factors, and the closely related 1.9III gene. By probing EcoR1-digested DNA with the Humhv3005/P1 probe, we found that one of the four major hybridizing bands was missing in $\sim 20 \%$ of patients with either rheumatoid arthritis or systemic lupus erythematosus, but only $2 \%$ of normal subjects. To delineate the genetic basis of this polymorphism, we have now employed the PCR to amplify and analyze hv3005, 1.9II, and homologous genes in individuals with characteristic RFLP genotypes. Our results indicate that the human Vh gene repertoire contains several hv3005- and 1.9III-like genes, and that a complete deletion of the hv3005like genes is relatively restricted to a subset of autoimmune patients. These findings provide initial evidence for deletion of developmentally regulated autoreactive $\mathrm{V}$ genes in autoimmune diseases. (J. Clin. Invest. 1991. 88:193-203.) Key words: fetal antibody repertoire $\bullet$ antibody network $\bullet$ polymerase chain reaction • rheumatoid arthritis • systemic lupus erythematosus
\end{abstract}

\section{Introduction}

Autoantibodies of given specificities are often associated with different human autoimmune diseases and may contribute in some instances toward the induction and/or severity of tissue damage $(1,2)$. Paradoxically, recent studies in humans and mice revealed that several autoantibodies were found regularly in apparently healthy individuals and were encoded directly by

Address correspondence and reprint requests to Dr. Tsaiwei Olee, Department of Medicine-0945, University of California, San Diego, La Jolla, CA 92093-0945.

Received for publication 2 April 1990 and in revised form 16 January 1991.

J. Clin. Invest.

(C) The American Society for Clinical Investigation, Inc.

0021-9738/91/07/0193/11 \$2.00

Volume 88, July 1991, 193-203 germline Ig variable region $(\mathrm{V})^{1}$ genes with no somatic mutation (3-16). In addition, serological analyses of newborn mice showed a high frequency of autoreactive B cells, whose expressed autoantibodies often shared cross-reactive idiotypes (CRIs) (17-19). Further, molecular analyses of the neonatal antibody repertoire in humans and mice indicated that a restricted set of $\mathrm{Vh}$ genes were expressed preferentially, and that such early expressed Vh genes frequently encoded idiotypically related autoantibodies $(8,10,13,20-30)$.

Combined, these findings suggested that autoantibodies may serve some important physiological functions of the immune system, by augmenting the opsonization of infectious agents, and the clearance of immune complexes and senile cells (reviewed in references 4, 6, 7, 29 and 31). It was also postulated that the developmentally regulated autoantibodies might interact with each other to exert long term regulatory effects on the expressed antibody repertoire $(5,32,33)$. In this context, it is conceivable that a homozygous deletion of an important autoreactive $\mathrm{V}$ gene may lead to an aberrant antibody and $\mathrm{B}$ cell repertoire, and thereby predispose to the induction and/or continuation of "inherited" autoimmune diseases.

To examine this possibility, we reasoned that the autoreactive $\mathrm{V}$ gene expressed most frequently in a fetal liver might be most important in the development of the humoral immune system. Accordingly, we searched for and isolated a putative germline gene counterpart to the 56P1 sequence, the $\mathrm{Vh}$ gene expressed most frequently in a 130-d fetal liver (34). This germline gene, designated Humhv3005, encodes an amino acid sequence identical to the 56P1 sequence, and to the heavy chain of a B6 CRI positive rheumatoid factor (RF), except for a single amino acid difference $(27,28,34-36)$. In addition, the hv3005 gene is $99 \%$ homologous to the 1.9 III germline Vh gene, which in turn is identical to the heavy chain of the kim4.6 anti-DNA antibody $(11,37)$. Subsequently, Southern analysis of EcoR1digested DNA with the Humhv3005/P1 probe revealed four hybridizing bands. Remarkably, among these, one band of 9.4 $\mathrm{kb}$ in size was absent in $~ 20 \%$ of patients with RA or SLE, but was missing in only $2 \%$ of normal individuals (38). By chisquare analyses, the 9.4-kb-band deletion was significant for patients with RA or $\operatorname{SLE}\left(\chi^{2}=7.62, P<0.01\right)$. To delineate the molecular basis of this disease-linked deletion, we have now employed the PCR to amplify specifically the hv3005-like genes, and analyzed these genes in selected individuals (39).

1. Abbreviations used in this paper: CDR, complementary-determining region; CRI, crossreactive idiotype; FR, framework region; RF, rheumatoid factor; $\mathrm{V}$, variable. 
We found that eight of nine subjects lacking the 9.4-kb band had only the 1.9III-like genes, but no hv3005-like genes. Taken together with the previous RFLP data, these findings provide preliminary evidence for deletion of developmentally regulated autoreactive $\mathrm{V}$ genes in autoimmune diseases.

\section{Methods}

Genomic DNA and Southern blot analyses. Genomic DNAs were prepared from peripheral blood leukocytes of selected individuals who displayed representative RFLP profiles as defined by either the Humhv3005/E1.6 or the Humhv3005/P1 probes $(38,40)$. Previously, we had suggested that BamH1 digestion of DNA with the hv3005/E1.6 probe could separate the $1.91 \mathrm{II}$ and the Humhv $3005 \mathrm{Vh}$ gene loci into respective bands of 6 and $5.2 \mathrm{~kb}(40)$. Accordingly, an individual with a strong $6-\mathrm{kb}$ band and a weak $5.2-\mathrm{kb}$ band was postulated to have two copies of the 6-kb/1.9III region and one copy of the $5.2-\mathrm{kb} / \mathrm{hv} 3005$ region per diploid genome, denoted by the $(6,6,5,0)$ genotype. On the other hand, when EcoR1-digested DNA was analyzed with the Humhv3005/P1 probe, there were four major hybridizing bands, of 16 , $10,9.4$, and $5.2 \mathrm{~kb}$ in size (38).

For Southern blot analyses with the Humhv3005/P1 probe, each genomic DNA sample was digested separately with the EcoR1 restriction enzyme, and the lysates were loaded into wells of an agarose gel. After electrophoresis and transfer of DNA to nitrocellulose, the blots were hybridized with hv3005/P1, a 466 bp Pst 1 fragment located about $1 \mathrm{~kb}$ upstream of the Humhv3005 gene (38). Hybridizations were done in $5 \times \operatorname{SSC}(1 \times \mathrm{SSC}=0.15 \mathrm{M} \mathrm{NaCl} / 0.015 \mathrm{M}$ sodium citrate, $\mathrm{pH} 7.0)$ at $65^{\circ} \mathrm{C}$, followed by washing twice in $0.1 \times \mathrm{SSC}$ at $65^{\circ} \mathrm{C}$.

Oligomers. Three primers were prepared for the PCR-based amplification of the Humhv3005 and closely related Vh genes. They were hv3005U1s ( $U$ and $s$ stand for the upstream region and the sense strand), hv3005D1c (D and c indicate the downstream region and the complementary strand, respectively), and hv3005D2c, corresponding, respectively, to nucleotide positions from -135 to -116 , from 339 to 320 , and from 488 to 467 (the first two are underlined in Fig. 1). A Sall site was added to the $5^{\prime}$ end of hv3005U1s, while a BamH1 site was added to the $5^{\prime}$ end of each downstream primer.

In addition, we prepared nine oligomers specific for hv3005, 1.9III, 56P1, and p6 (see Results). They were: $(a)$ hv3005C1s (where $\mathrm{C} 1$ stands for the first complementarity-determining region [CDR]), corresponding to nucleotides from positions 88 to 108 ; $(b) \mathrm{hv} 3005 \mathrm{C} 2 \mathrm{~s}$, corresponding to nucleotides from 145 to 168 , mainly in the second CDR of hv3005; (c) hv3005F2s (where F2 stands for the second frame work region [FR] of hv3005), corresponding to nucleotides from 126 to 145; (d) $1.9 \mathrm{IIIC}$ s, similar to hv3005C1s except for a two base difference at positions 98 and $99 ;(e) 1.9$ IIIF3s, corresponding to nucleotides from 284 to 303 in the third FR of $1.9 \mathrm{III} ;(f)$ p6F 1 s, corresponding to nucleotides from 63 to 82 in the first FR of p6; $(g)$ p6C2s, corresponding to nucleotides from 146 to 165 , mainly in the second CDR of p6; $(h)$ p6F3s, corresponding to nucleotides from 255 to 274 in the third $F R$ of p6; and (i) $56 \mathrm{P} 1 \mathrm{C} 2 \mathrm{~s}$, corresponding to nucleotides from 159 to 178 in the second CDR of 56P1. The locations of oligomers 1, 2, and 4 are indicated in Figs. 1 and 3, while those of oligomers 3, 5, 6, 8, and 9 are indicated in Fig. 4.

Polymerase chain reaction of the selected VH3 genes. To amplify the selected Vh3 gene(s), $1 \mu \mathrm{g}$ of genomic DNA from a chosen individual was mixed with $50 \mathrm{pmol}$ of hv3005U 1s and $50 \mathrm{pmol}$ of hv3005Dlc in a buffer containing $1 \mathrm{mM} \mathrm{Mg}^{++}$. After the mixture had been heated at $95^{\circ} \mathrm{C}$ for $5 \mathrm{~min}$ and then chilled to $40^{\circ} \mathrm{C}$, all four deoxynucleotides and Taq polymerase were added, and the final mixture was incubated for 30 cycles. Each consisted of $1 \mathrm{~min}$ annealing at $55^{\circ} \mathrm{C}, 1.5 \mathrm{~min}$ (except for $5 \mathrm{~min}$ in the last cycle) elongation at $72^{\circ} \mathrm{C}$, and $1 \mathrm{~min}$ dissociation at $95^{\circ} \mathrm{C}$. After amplification, the reaction mixture was extracted once with TE buffer ( $10 \mathrm{mM}$ Tris and $1 \mathrm{mM}$ EDTA) saturated phenol, precipitated, and resuspended in $100 \mu \mathrm{l}$ of TE buffer.
M13mp8 subcloning, screening, and sequencing. The amplified DNA was digested sequentially with Sall and BamH1, and was then subcloned into Sal1-BamH1-digested M13, according to established protocols (41). The recombinant phages were screened with the indicated oligomers, with hybridization done in $6 \times$ SSPE $(20 \times$ SSPE is 3.6 $\mathrm{M} \mathrm{NaCl} / 200 \mathrm{mM}$ sodium phosphate, pH 7.4/20 mM EDTA, pH 7.4) containing $5 \times$ Denhart's solution ( $1 \times$ is $0.02 \%$ Ficoll $/ 0.02 \%$ polyvinylpyrrolidone $/ 0.02 \%$ bovine serum albumin), at $\left(T_{\mathrm{d}}-10\right){ }^{\circ} \mathrm{C}$, where $T_{\mathrm{d}}$ (the temperature at which half of the duplexes are dissociated) $=2 \times[\mathrm{A}$ $+T]+4 \times[G+C](42,43)$. Hybridized filters were washed four times at room temperature for $15 \mathrm{~min}$ each, and then one time at $T_{\mathrm{d}}{ }^{\circ} \mathrm{C}$ for 1 min. Single-stranded DNA was prepared from the chosen M13 clones, and was sequenced with the universal M13 sequencing primer, hv3005Cls, or 1.9IIICls. The computer programs of the Genetics Computer Group (University of Wisconsin, Madison, WI) were used to assemble, edit, and analyze all sequence data (44).

Asymmetric amplification and direct sequencing. Each DNA sample was amplified simultaneously in two separate reaction mixtures, each consisting of $1 \mu \mathrm{g}$ of genomic DNA, and $20 \mathrm{pmol}$ of hv3005D2c with either 1 or 2 pmol of hv3005U1s as the limiting primer. The mixtures were incubated for 45 cycles; each comprised of $1.5 \mathrm{~min}$ annealing at $55^{\circ} \mathrm{C}, 2 \mathrm{~min}$ elongation at $72^{\circ} \mathrm{C}$, and $1 \mathrm{~min}$ dissociation at $95^{\circ} \mathrm{C}$. The amplified DNA was extracted once with TE-saturated phenol, precipitated, resuspended in TE buffer, and sequenced with the limiting primer.

\section{Results}

M13 subcloning and sequencing of the amplified hv3005- and 1.9III-like genes. To select the appropriate primers for the specific amplification of hv3005-like genes, we compared the hv3005 and the 1 .9III sequences with most published Vh3 sequences which we had entered into our computer database (34, $37,45-47)$. Since most reported $\mathrm{Vh}$ gene sequences start at the first base for the leader region, sequence comparison was initiated at this position. The results showed that hv3005 and 1.9III differ from all other Vh3 genes by at least three bases from positions -135 to -116 (underlined in Fig. 1). Accordingly, a 5 '-end primer corresponding to this stretch was prepared and designated as hv3005U1s. By a similar procedure, we prepared two 3'-end primers (designated hv3005D1c and hv3005D2c) that were complementary, respectively, to nucleotide positions from 339 to 320 (underlined in Fig. 1) and from 488 to 467.

In our first trial, we used the hv3005U1s and hv3005D1c as primers to amplify genomic DNA from an individual (Fer) with the $(0,0,5,5) \mathrm{hv} 3005 / \mathrm{E} 1.6$-defined genotype (see Methods) (40). After 30 cycles of PCR, the amplified DNA was shown to contain one major band of the expected size that also hybridized with the hv3005C 2 s oligomer (data not shown). This oligomer is the same as the reported H61 oligomer, which had been shown to hybridize with only one to two major bands in Taq1-digested DNA, indicating that the oligomer is specific for hv3005- and 1.9III-like genes (48).

The amplified DNA was then subcloned into M13mp8, and the recombinant phages were screened with hv3005C2s. Among 85 recombinant (colorless) M13, 78 (92\%) were positive, indicating that the amplification of hv3005- and 1.91IIlike genes was highly specific. Subsequently, the M13 filters were reprobed with the hv $3005 \mathrm{C} 1 \mathrm{~s}$ oligomer; it centers upon a two-base difference between hv3005 and 1.9III genes in the first CDR. This oligomer is the same as the reported H138 oligomer, that had been shown to hybridize more strongly to one of the two hv3005C2s hybridizing bands in Taq1-digested DNA, indicating that it can discriminate between the hv3005- 


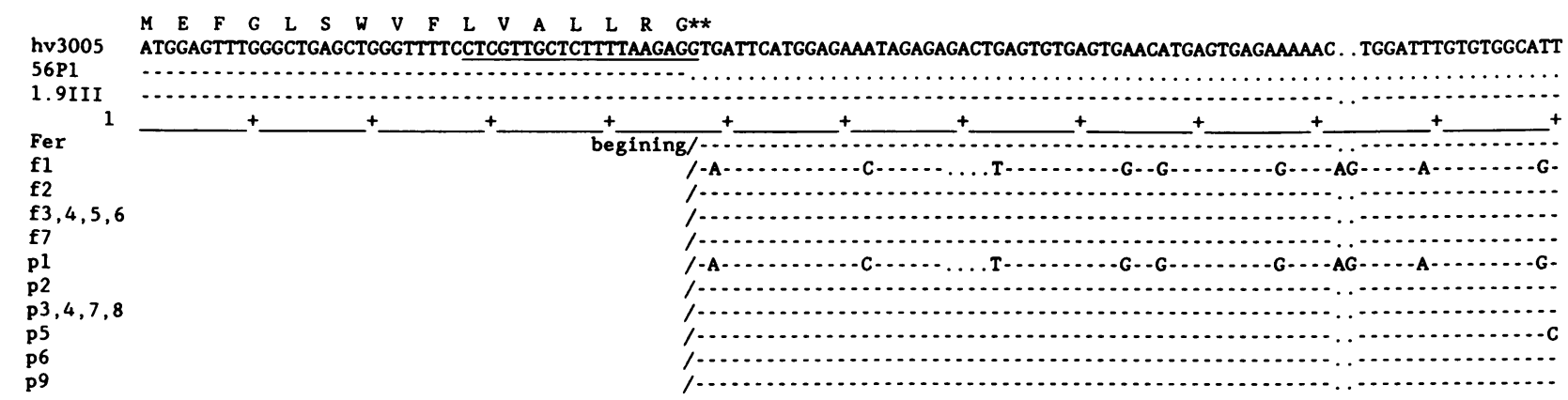

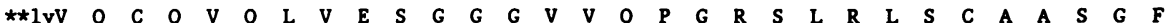
hv3005 TTCTGATAACGGTGTCCTTCTGTTTGCAGGTGTCCAGTGTCAGGTGCAGCTGGTGGAGTCTGGGGGAGGCGTGGTCGAGCCTGGGAGGTCCCTGAGACTCTCCTGTGCAGCCTCTGGATT

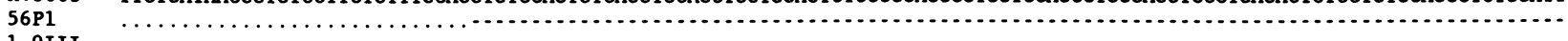

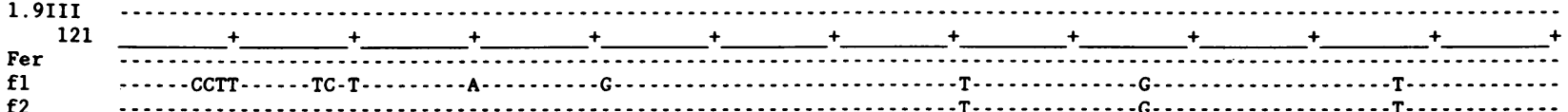

f2 $\quad\left[\begin{array}{ll}\text { f } \\ \text { f }\end{array}\right.$

f3,4,5,6

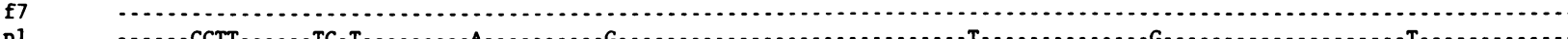

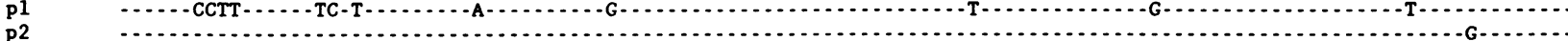

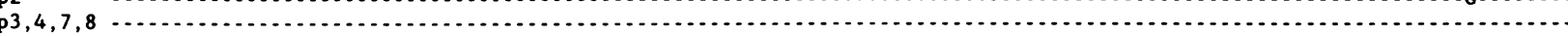

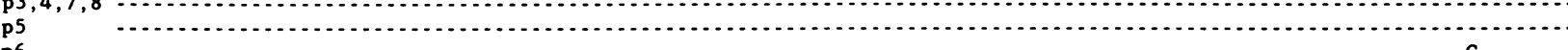

P6

CDR1

CDR2

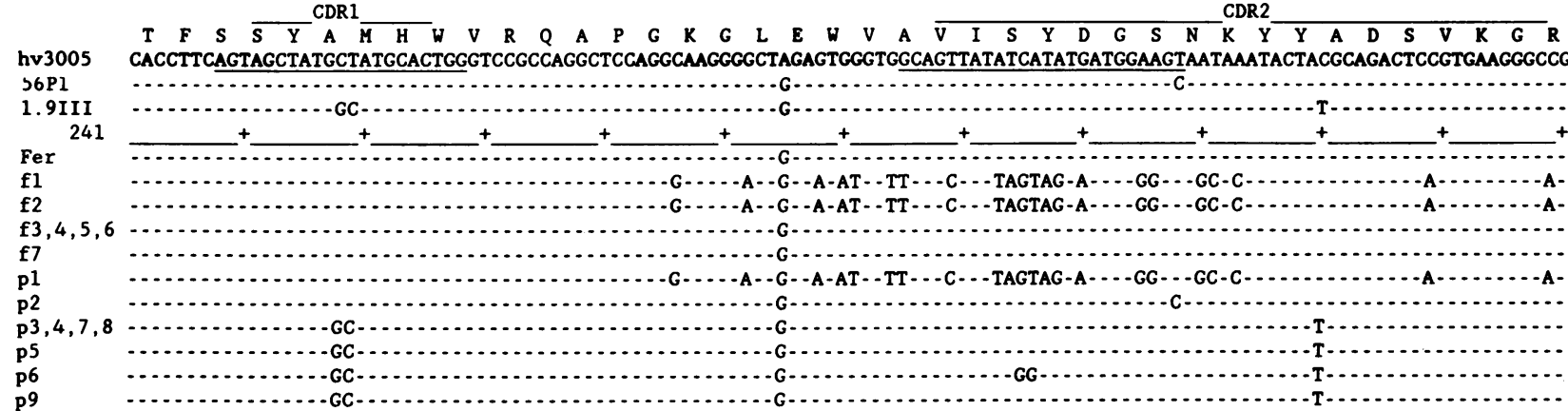

$\begin{array}{llllllllllllllllllllllllllllll}I & S & R & D & N & S & K & N & T & L & Y & L & Q & M & N & S & L & R & A & E & D & T & A & V & Y & Y & C & A & R & *\end{array}$

56p1 1 .

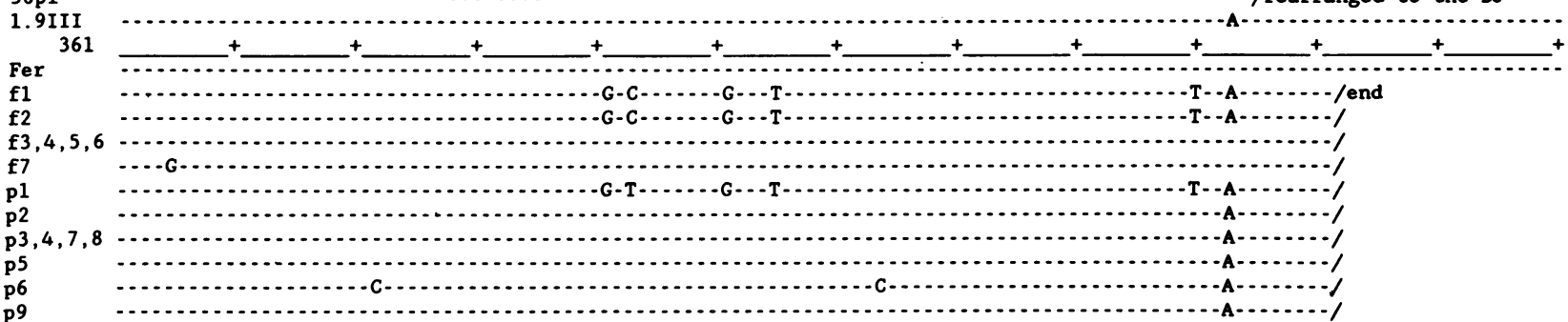

$\star \star *$-mer**

hv3005 GCCCAGACACAAACCTCCCTGCAGGAACGCTGGGGGAAATCAGCGGCAGGGGGCGCTCAGGAGCCACTGATCAGAGTCAGCCCTGGAGGCAGGTGCAGATGGAGGCTGTTTCCTGTCAG

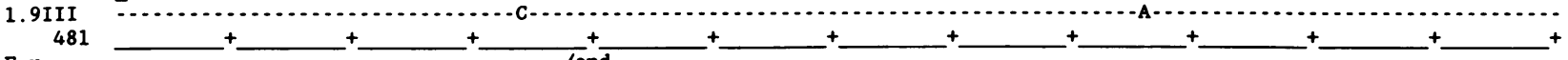

Figure 1. Nucleotide sequences of hv3005- and 1.91I-like genes in two selected individuals; f1-f7 and p1-p9 denoted the sequences of M13 clones derived, respectively, from Fer and Pla, whereas Fer denoted the result of direct sequencing of the amplified Fer DNA. The sequences of the hv3005 and the 1.9III genes, and the 56P1 cDNA sequence are included for comparison. The complete nucleotide and amino acid sequences of Humhv3005 are given, while other sequences are given only at the positions where they differ from the hv3005 sequence. All sequences were first aligned for maximum homology, the nucleotides identical to hv3005 are indicated by bars while the introduced gaps are marked by dots, which also indicate the unsequenced region in 56P1. The CDRs, the conserved nucleotide sequences for splicing and rearrangement, and three PCR primers are marked. 
and the 1.9III-like genes (48). Of 85 recombinant M13 phages, 80 were positive with hv $3005 \mathrm{Cls}$, including all $78 \mathrm{hv} 3005 \mathrm{C} 2 \mathrm{~s}^{+}$ ones. Both $\mathrm{C}_{1}{ }^{+} \mathrm{C} 2 \mathrm{~s}^{-}$clones (designated $\mathrm{f} 1$ and $\mathrm{f} 2$ ) and five double positive clones (designated $\mathrm{f} 3$ to $\mathrm{f} 7$ ) were sequenced.

The sequences of $\mathrm{f}$ to $\mathrm{f} 6$ were identical to each other, and differed by only one base from hv3005 at nucleotide position 135 (Fig. 1). Importantly, this single base difference between hv3005 and the PCR amplified $\mathrm{f} 3-\mathrm{f} 6$ insured that the latter sequences were not amplified from a contaminating hv3005 gene, but rather represented a new Vh3 gene, designated Humhv3005f 3 . The $f 7$ sequence deviated from hv3005f 3 by only one base at nucleotide position 205 , which was likely an artifact due to infidelity of the Taq polymerase. The f1 and $f 2$ sequences of two $\mathrm{C}^{-} \mathrm{s}^{-}$clones were quite interesting; they differed significantly from both hv3005 and 1.9III sequences, yet were identical to each other over a stretch of $300 \mathrm{bp}$, from nucleotide positions 2 to 301 (Fig. 1). However, f2 was also identical to $3-\mathrm{f} 6$ from positions -113 to 30 . Together, these data suggested that the 11 sequence probably represented a new Vh gene, while $\mathrm{f} 2$ might be a hybrid molecule with its 5 '-end derived from $\mathrm{f} 3$ and its 3 '-end from $\mathrm{f} 1$, produced as a PCR artifact, similar to a previous observation by others (49). Nevertheless, the combined sequence data of $\mathrm{f} 3-\mathrm{f} 7$ (excluding the $\mathrm{f} 1$ and the $\mathrm{f} 2$ sequences with unknown germline counterparts) indicated that the maximum number of possible PCR errors was $1 / 2,060 \mathrm{bp}(=412 \times 5)$.

In the second trial, we used the DNA from Pla, who had the $(6,6,0,0)$ hv3005/E1.6-defined genotype (40). The amplified DNA was subcloned into M13 and the recombinant phages were screened first with 1.9IIIC1s. The result showed that 531/ 539 clones $(99 \%)$ were positive. In addition, rescreening with hv3005C1s revealed two of the eight $1.91 \mathrm{IIC} 1 \mathrm{~s}^{-}$were positive, designated p1 and p2. The latter two clones and seven 1.9IIIC1s $\mathrm{s}^{+}$clones (designated p3-p9) were sequenced.

The p3, p4, p7, and p8 sequences were identical to 1.9 III (Fig. 1). Because we did not have the cloned 1.9III gene in our laboratory at the time of these experiments, there was no possibility of contamination. The p5 sequence deviated from 1.9 III by one base at position -41 , and the $p 9$ sequence had a single base deletion at nucleotide position 36 . Both differences apparently represented amplification or compression artifacts. The p6 sequence differed from the p3 sequence by $5 \mathrm{bp}$, located at nucleotide positions $72,155,156,222$, and 264 .

Of the two hv3005 $\mathrm{Cls} \mathrm{s}^{+}$clones, the p1 sequence was almost identical to the f1 sequence over a stretch of $412 \mathrm{bp}$, and differed by only one base at nucleotide position 243 . This result supported the earlier contention that the f1 sequence apparently represented a new $\mathrm{Vh} 3$ gene. The single base difference between these two sequences from two unrelated individuals could be due to amplification artifact, allelic difference, or two different $\mathrm{Vh} 3$ genes in a haploid genome. The remaining p2 sequence was similar to hv3005, having only four base differences. Interestingly, of these four different bases, two were shared by the 56P1 sequence, one was shared by $\mathrm{p} 3$, and one was shared by $p 6$. The data thus suggested that the $p 2$ sequence was very likely to represent an authentic germline $\mathrm{Vh} 3$ gene sequence. However, it was hardly credible that the ratio of the copy numbers of two $\mathrm{Vh}$ genes were $\sim 260$ to 1, i.e., 531 for $1.9 \mathrm{III}$ and $\mathrm{p} 6$ genes, and 1 for the putative p2 gene. Rather, we suspected that $\mathrm{p} 2$ might derive from contamination of the Pla DNA with genomic DNA of an unknown individual. Unfortunately, we had used all the Pla DNA and had no identity of the donor (Pla was only a laboratory designation). Thus, this issue can not be resolved at this time.

Regarding the five single base differences between $\mathrm{p} 6$ and $1.9 \mathrm{III} / \mathrm{p} 3$, only the $\mathrm{G}$ nucleotide at position 72 was shared with the $\mathrm{p} 2$ sequence. However, the sequence data of $\mathrm{p} 3-\mathrm{p} 5$ and p7-p9 (excluding p1, p2, and p6 with unknown germline counterparts) indicated that the maximum number of possible PCR errors in Pla was $2 / 2,472$. Combined with the sequence data of f3-f7, the overall number of possible PCR errors was $3 / 4,944$ or $1 / 1,648$. This figure is similar to the error rate of PCR observed by others $(50,51)$. Accordingly, it is unlikely that most of the five base differences between p6 and p3 were artifacts; rather, the p6 sequence most likely represents a new Vh3 gene. It should be mentioned that the sequences of $\mathrm{p} 5$ and $\mathrm{p} 6$ during the initial analyses of $\mathrm{p} 1$ to $\mathrm{p} 7$ clones led us to characterize two additional clones, $\mathrm{p} 8$ and $\mathrm{p} 9$.

Direct sequencing of PCR-amplified DNA reveals that the 9.4-kb band contains HUMHV3005-like genes. Having established that PCR with hv3005U1s and hv3005D1c amplified mainly the hv3005- and the 1.9III-like genes, we used the Fer DNA to work out conditions for asymmetric amplification and
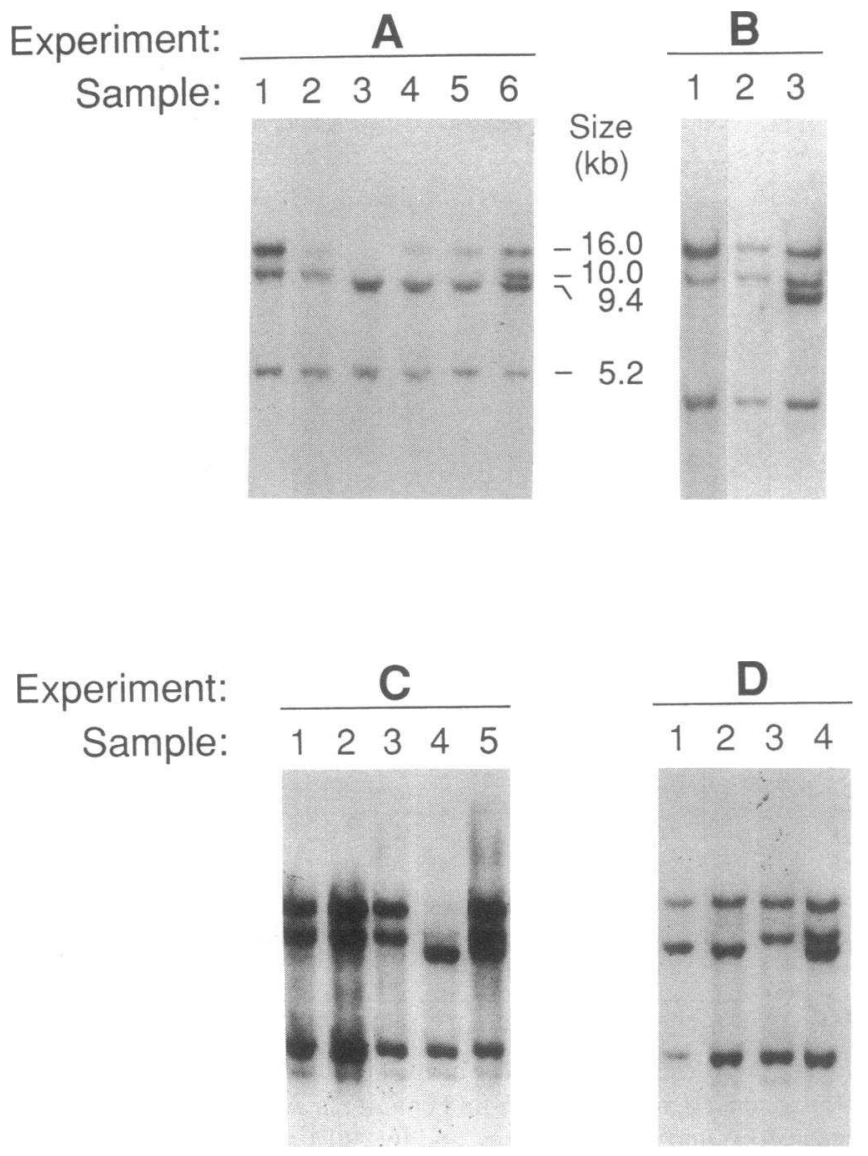

Figure 2. Southern blot analyses of the EcoRI-digested DNA samples, whose Humbv 3005 and related genes were examined by asymmetric PCR amplification and direct sequencing (Fig. 3). These DNA samples were analyzed in four separate experiments, thus the results are presented in four panels, each with a control DNA that displays all four characteristic hv3005/P1-hybridization bands. The DNA samples are: Fie, Ola, Fer, Sta, and Har (for lanes 1-5, respectively) in $A$; Rob and The in $B$; Tay, Rey, Can, and Bec in $C$; Baj, Noc, and Nov in $D$. 


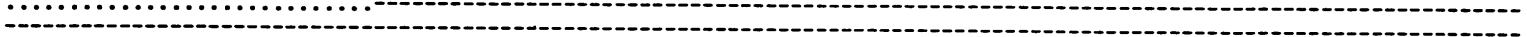
-

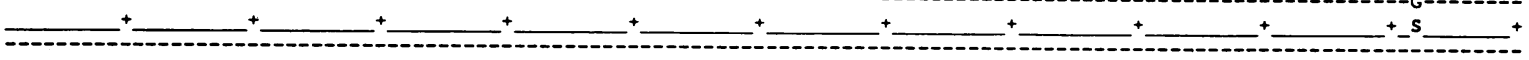
${ }^{2}$
$\mathrm{n}$ CDR1 CDR2

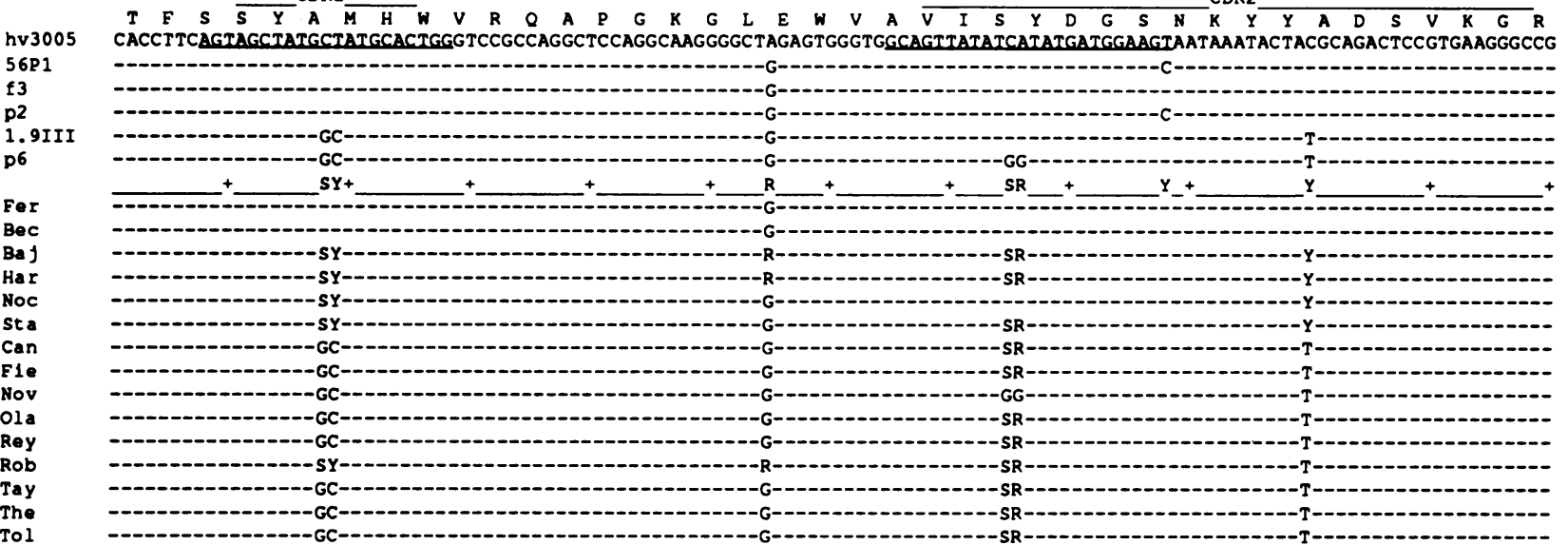

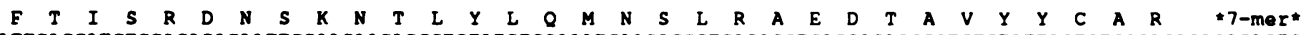

hv3005 ATTCACCATCTCCAGAGACAATTCCAAGAACACGCTGTATCTGCAAATGACAGCCTGAGAGCTGAGGACACGGCTGTGTATTACTGTGCGAGAGACACAGTGAGGGGAGGTCATTGTGC

56p1

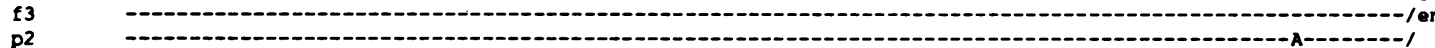

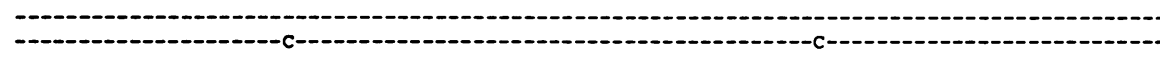

Fer

BeC

Ba

Figure 3. Direct sequence analyses of amplified DNA from 10 individuals who displayed the representative hv3005/P1 hybridizing patterns in EcoR1-digested DNA, they are: Fer and Bec who lacked the 16- and 10-kb bands; Baj, Har, Noc, and Sta who lacked the 10-kb band; Can, Fie, Nov, Ola, Rey, Rob, Tay, The, and Tol who lacked the 9.4-kb band. The sequences of hv3005, 56P1, f3, p2, 1.9III, and p6 are included for comparison. The complete nucleotide and amino acid sequences of Humhv3005 are given, while other sequences are given only at the positions where they differ from the hv3005 sequence. The nucleotide combinations at the restricted positions are indicated by the symbols: $R$ for $A \&$ G; $S$ for C \& G; $Y$ for C \& T. All sequences were first aligned for maximum homology, the nucleotides identical to hv3005 are indicated by bars, while the introduced gaps are marked by dots, which also indicate the unsequenced region in 56P1. The CDRs and the conserved nucleotide sequences for splicing and rearrangement are marked.

direct sequencing of these genes. Initial trials using the hv3005U1s and hv3005Dlc revealed difficulty in reading the last 20 nucleotides immediately before the hv3005D1c primer. Accordingly, we prepared a new primer, designated
hv3005D2c, and used this one in all subsequent asymmetrical amplification and direct sequencing.

Thereafter, we analyzed DNA samples from 14 unrelated individuals, who were selected on the basis of their hv3005/P1-

Deletion of an Autoreactive V Gene in Autoimmune Diseases 


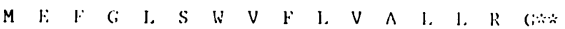

hv3005 ATGGAGTTTGGGCTGAGCTGGGTTTTCCTCGTTGCTCTTTTAAGAGGTGATTCATGGAGAAATAGAGAGACTGAGTGTGAGTGAACATGAGTGAGAAAAAC. .TGGGATTTGTTGTGGCATT

$56 \mathrm{Pl}$

$1,9 \mathrm{III}$
$\mathrm{f3} ; \mathrm{p} 2,6$ b1-6,9-13,15-31,33$, 35,37-39,41,43-45,47-52,54-56$
b32

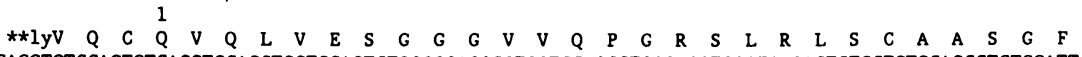
hv3005 TTCTGATAACGGTGTCCTTCTGTTTGCAGGTGTCCAGTGTCAGGTGCAGCTGGTGGAGTCTGGGGGAGGCGTGGTCCAGCCTGGGAGGTCCCTGAGACTCTCGTGTGCAGCCTCTGGATT

$56 \mathrm{P} 1$
$\mathrm{f} 3$

P2 1.9 III

p6 121

b1 $-6,16,17,20-24,38,39,44,45,47,49-51,55$

b25

b37

b43

b36

b 41

b5 5,56

b9- $12,33,35$

b28

b13,15 -

b18, 19, 27, 31

b2 2

b29
b32

h6300

f3

f3
1.911

p6 6 III

(...........................

(1............

(n)

35

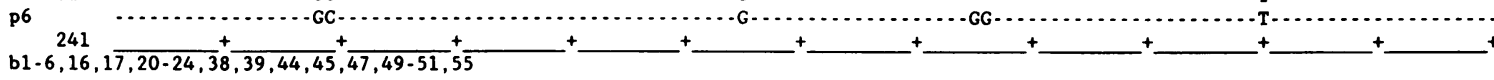

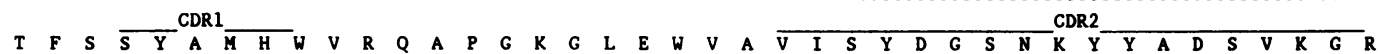

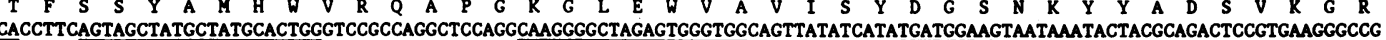
CACCTTCAGTAGCTATGCTATGCACTGGGTCCGCCAGGCTCCAGGCAAGGGGCTAGAGTGGGTGGCAGTTATATCATATGATGGAAGTAATAAATACTACGCAGACTCCGTGAAGGGCGG G .

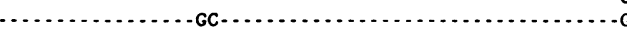

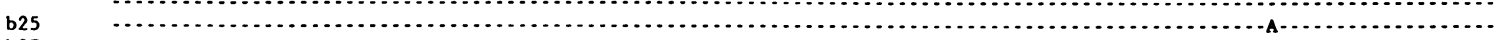

b42

b43

b48

b41

b52 54,56

b9-12, 33, 35

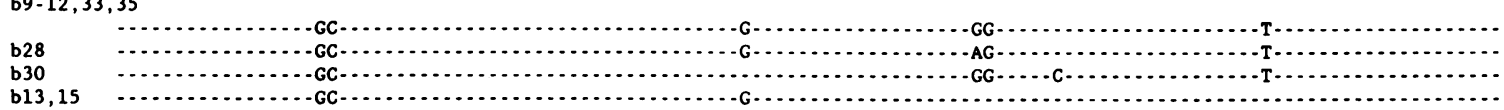

b18, 19, 27, 31

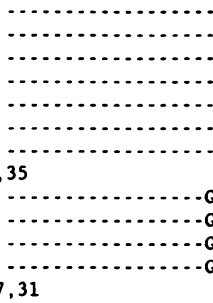

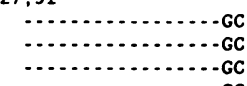

b2 9
b32

hv3005 ATTCACCATCTCCAGAGACATTCCAAGACACGCTGTATCTGCAMATGAACAGCCTGAGAGCTGAGGACACGGCTGTGTATTACTGTGCGAGAGACACAGTGAGGGGAGTCATTGTGC

$56 \mathrm{p} 1$
$\mathrm{f3}$

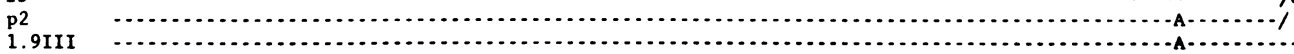

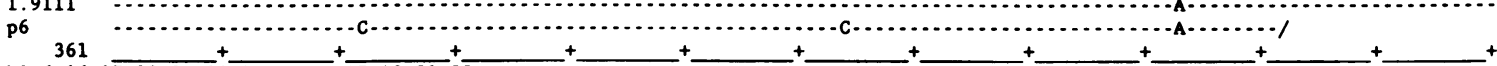

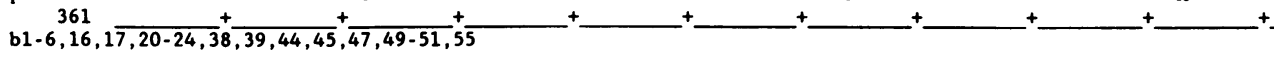

(1)

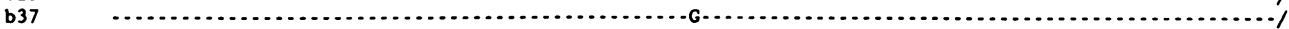

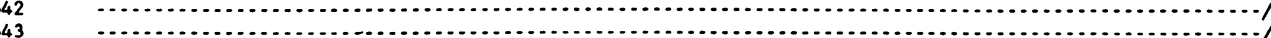

(n)

b36

45

$54,56,12,33,35$

b28

13,15

b18, 19, 27, 31

b26

b29 
defined genotype. Among them, one normal individual (Bec) lacked the 16- and 10-kb bands; two normals (Har and Sta) and two SLE patients (Baj and Noc) lacked the 10-kb band; one normal (The), four RA patients (Fie, Ola, Rey, and Tay), and four SLE patients (Can, Nov, Rob, and Tol) lacked the 9.4-kb band. The RFLP analyses of these DNA samples, except for Tol, are shown in Fig. 2; and the results of direct sequencing analyses of the asymmetrically amplified DNA are given in Fig. 3. As can be seen, the resultant sequences were very complex, and suggested that the human $\mathrm{Vh}$ gene repertoire contains a cluster of highly homologous $\mathrm{Vh}$ genes that differ from each other by single-base differences at five restricted positions and/ or by two-base differences at two other confined positions. Of these nine characteristic positions, each is comprised of two variable nucleotides. Importantly, eight of nine individuals who lacked the 9.4-kb band (i.e., Can, Fie, Ola, Nov, Rey, Tay, The, and Tol) had only G, C, and T nucleotides at positions 98 , 99 , and 180 , whereas both individuals who lacked the 16- and 10-kb bands (i.e., Fer and Bec) had only C, T, and C nucleotides at the corresponding positions (Figs. 2 and 3). Individual Rob had strong $G$ and $C$, with weak $C$ and $T$ (about one-fifth of the $G$ and $C$ intensities). To rule out any artifact due to unknown contamination of the Rob DNA, we repeated the PCR and sequencing with new Rob DNA prepared from freshly drawn blood, and obtained identical results. Collectively, the results showed that most individuals lacking the 9.4-kb band (except for Rob) did not have the hv3005-like genes, but had the 1.9III-like genes only. Conversely, the individuals lacking the 16- and 10-kb bands had only the hv3005-like genes, but not the 1.9III-like genes. Thus, the $9.4-\mathrm{kb}$ band contains the hv3005-like genes, while the 1.9III-like genes reside in both the 16- and the $10-\mathrm{kb}$ bands.

Characterization of several HUMHV3005- and 1.9III-like genes in a selected individual. To assess the complexity of hv3005- and 1.9III-like genes in humans, we subcloned the PCR-amplified DNA from Baj, in whom two legitimate variable nucleotides were present at each of eight selective locations (Fig. 3). The recombinant phages were screened sequentially with hv3005Cls, $1.9 \mathrm{IIIC} 1 \mathrm{~s}$, and six additional 20-mers that center upon the characteristic nucleotides of four different Vh sequences. These are: $(a)$ p6F1s, corresponding to a stretch of 20 bases that centers upon the $G$ nucleotide at position 72 in the first FR of p6; $(b)$ hv3005F2s, that centers upon the A nucleotide at position 135 in the second FR of hv3005; (c) p6C2s, that centers upon the GG nucleotides at positions 155 and 156 in the second CDR of p6; $(d) 56 \mathrm{P} 1 \mathrm{C} 2 \mathrm{~s}$, that centers upon the $\mathrm{C}$ nucleotide at position 168 in the second CDR of $56 \mathrm{P} 1 ;(e)$ p6F3s, that centers upon the $C$ nucleotide at position 264 in the third FR of p6; $(f)$ 1.9IIIF3s, that centers upon the A nucleotide at position 293 in the third FR of 1.9III.

Because we wanted to obtain a rapid approximation of the complexity of hv3005- and 1.9III-like genes, only one pair of recombinant phage filters were hybridized sequentially with all eight different probes, done routinely with hybridization in $6 \times$ SSPE at $\left(T_{\mathrm{d}}-10\right)^{\circ} \mathrm{C}$ and a final $1 \mathrm{~min}$ wash at $T_{\mathrm{d}}{ }^{\circ} \mathrm{C}$. Accordingly, the screening results could only be used as references in selecting clones for sequence analyses, but not as absolute data for identifying precisely the desired recombinant M13 clones; and the resultant sequence data could only be taken as a first approximation of the complexity of the hv3005- and the 1.9IIIlike genes. Because of base infidelity during the PCR amplification, each new $\mathrm{V}$ gene is defined by at least two completely identical sequences from the amplified DNA.

A total of 49 clones were sequenced completely, designated from $b 1$ to b56, with the exceptions of $b 7,8,14,34,40,46$, and 53. Among them, 22 sequences (represented by b1) were identical to hv3005, and the b41 sequence was identical to hv3005f3 (Fig. 4). The b54 and b56 sequences shared a complete identity, but differed from hv3005 by one silent base change at nucleotide position 264 , and thus defined a new $\mathrm{Vh}$ gene, designated Humhv3005b54. The b52 sequence differed from hv3005 by one silent base change at nucleotide position at 72 .

In addition to the hv3005-like genes in Baj, b13 and b15 were identical, but differed from 1.9 III by two single base changes, one of which led to an $\mathrm{Arg} / \mathrm{Lys}$ change at amino acid position 98, and thus represented a new $\mathrm{V}$ gene, designated Humhv3019b13. Similarly, four sequences (represented by b18) differed from 1.911 and hv3019b13, respectively, by three and one single base changes, and thus represented yet another new gene, designated Humhv3019b18. In addition, six sequences (represented by b9) differed from 1 .9III by three single bases and one double base, resulting in a Ser/Trp change at amino acid position 52 and a Arg/Lys change at amino acid position 98, and thus represented a new gene, designated Humhv3019b9. Besides these three 1.9III-like genes, b29 differed by one silent base change from hv3019b18 at nucleotide position 72 .

Among the remaining sequences, b25, b37, b42, b43, and b48 each differed by one unique base from hv3005, and b36 differed by two single bases from $\mathrm{hv} 3005 \mathrm{f} 3 / \mathrm{b} 41$. Sequences $\mathrm{b} 26$ and b32 differed from hv3019b18 by two and three bases, respectively, and sequences $b 28$ and $b 30$ differed from $h v 3019 b 9$ by one and two bases, respectively. Most of these differences were not shared with other homologous sequences and probably represented PCR artifacts.

Collectively, the current sequence data indicated that the Baj individual had at least three hv3005-like genes (i.e., $\mathrm{hv} 3005 / \mathrm{b} 1$, hv3005f3/b41, and hv3005b54), and three $1.9 \mathrm{III}-$ like genes (i.e., hv3019b9, hv3019b13, and hv3019b18). It was possible that hybrid molecules might be generated during the amplification process, and resulted in the false identification of some new $\mathrm{V}$ genes. As discussed earlier, we suspected that $\mathrm{f} 2$ could be a hybrid molecule that derived its 5 '-end from hv3005f3 and its 3'-end from f1 (Fig. 1). However, this mechanism was extremely unlikely to account for any of the new Vh

Figure 4. Baj contains several hv3005- and 1.9III-like genes. The Baj DNA was amplified and subcloned into M13. The recombinant phages were screened with the designed oligomers specific for hv3005, 1.91I, 56P1, and p6. These included (underlined): p6F1s (from 63 to 82), hv3005C1s, hv3005F2s (from 126 to 145), 56P1C2s (from 159 to 178), p6F3s (from 255 to 274), 1.9IIF3s (from 284 to 303). The sequences of hv3005, 56P1, f3, p2, 1.9III, and p6 are included for comparison. The complete nucleotide and amino acid sequences of Humhv3005 are given, while other sequences are given only at the positions where they differ from the hv3005 sequence. All sequences were first aligned for maximum homology, the nucleotides identical to hv3005 are indicated by bars, while the introduced gaps are marked by dots, which also indicate the unsequenced region in 56P1. The CDRs and the conserved nucleotide sequences for splicing and rearrangement are marked. 


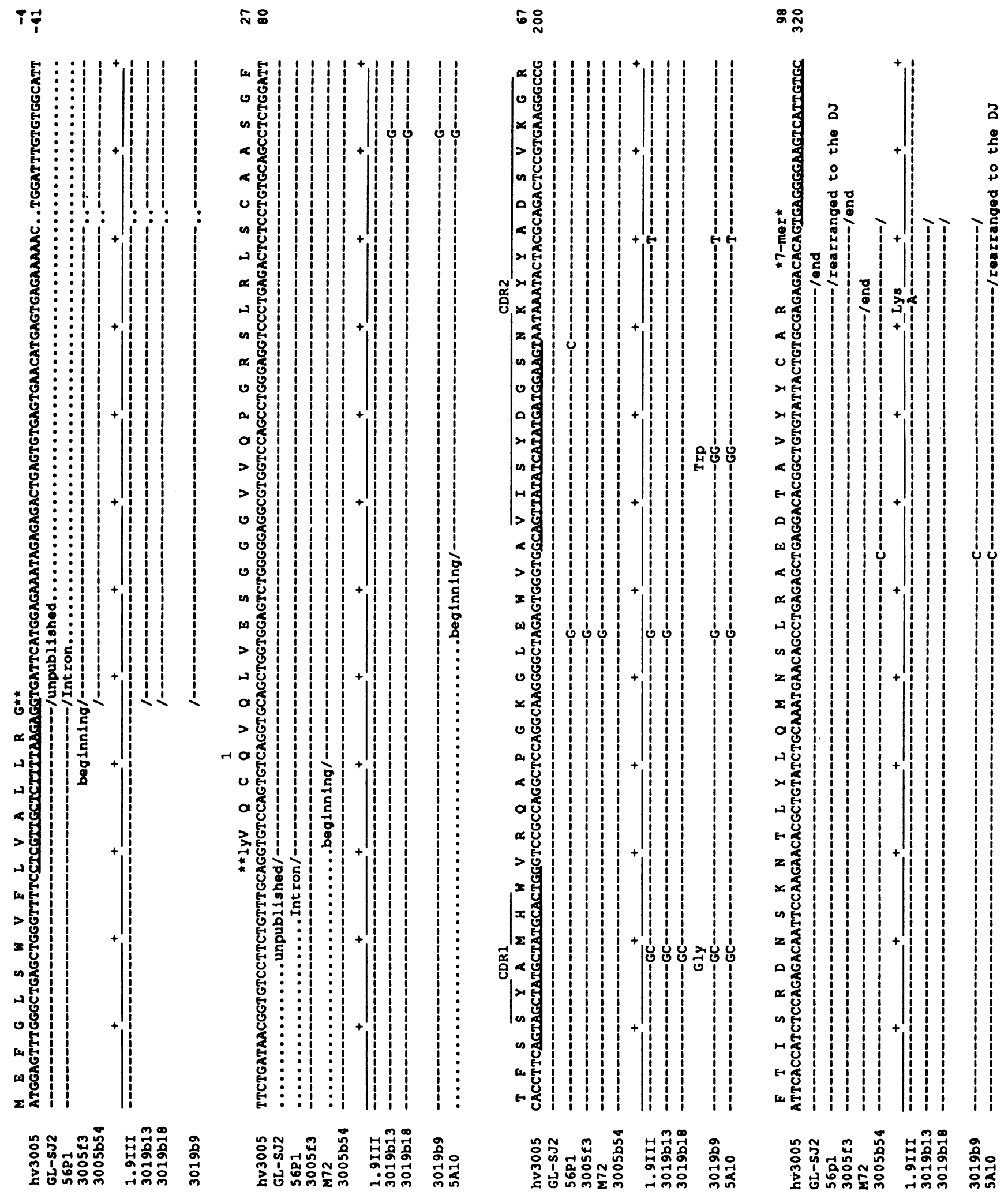


genes identified in Baj, as all seven sequences with $G G$ at positions 155 and 156 (i.e., b9-b12, b33, b35, and b30) had G at position $72, \mathrm{GC}$ at positions 98 and $99, \mathrm{~T}$ at position 180 , and $\mathrm{C}$ at position 264 , and that all $32 \mathrm{hv3005}$-like sequences had only $\mathrm{T}$ at position 264 . Thus, the current sequence data of Baj showed that there were six highly homologous Vh genes in this individual.

\section{Discussion}

A series of experiments were performed in an effort to delineate the genetic meaning of a disease-associated RFLP of a developmentally regulated autoreactive $\mathbf{V}$ gene. First, we established that the hv3005, 1.9III, and closely related genes could be specifically amplified, using carefully designed hv3005-specific primers (identified by extensive sequence comparison) and genomic DNA from individuals selected on the basis of their hv3005/E1.6-defined RFLP genotypes. Then, we modified the method such that we were able to amplify and sequence directly hv3005-related genes in several selected individuals who had representative hv3005/P1-defined genotypes. Importantly, eight of the nine individuals lacking the 9.4-kb hv3005/P1 hybridizing band in EcoR1-digested DNA had only the 1.9III-like genes, but not the hv3005-like genes. Taken together with the finding of a nearly restricted deletion of the 9.4-kb band in autoimmune patients, the current data provide preliminary evidence for homozygous deletion of developmentally regulated autoreactive $\mathrm{V}$ gene(s) in autoimmune diseases.

It should be pointed out that, in addition to overt deletion of some biologically important $\mathrm{V}$ genes, a single base mutation in either the regulatory region or the coding region of a critical $\mathrm{V}$ gene might severely affect its expression or function, thereby exerting the same pathophysiological consequence as deletion. Thus, in addition to $20 \%$ of patients with RA and SLE who apparently delete the entire hv3005-like genes, it is conceivable that a subset of the remaining autoimmune patients may have either nonfunctional hv3005-like genes due to base changes in a critical regulatory region, or disease-related form(s) of hv3005-like genes with a unique amino acid residue at a certain position. In the latter regard, hv3005 has Arg at position 98, whereas hv3005f3 has Lys, due to a $G$ to A transition. Therefore, it may be important to further analyze the hv3005-like genes in patients and normals, particularly at nucleotide position 293 , in order to determine whether one of these two residues is associated with autoimmune diseases.

In addition to defining the homozygous deletion of hv3005-like genes in some autoimmune patients, this study reveals new aspects of the heterogeneity and complexity of the human Vh gene locus. As described here, some human diploid genomes have as few as one hv3005-like gene (i.e., hv3005f3 in Fer) or one 1.9III-like gene (i.e., 1.9III in Pla). In contrast, the limited analyses of the amplified DNA from Baj reveal three hv3005-like genes (i.e., b1 $=$ hv3005, b41 $=$ hv3005f 3 , hv3005b54) and three 1.9III-like genes (i.e., hv3019b9, hv3019b13, hv3019b18). All five newly identified Vh genes were defined by at least two identical sequences from PCR-amplified DNA, to rule out the possibility of base infidelities created during PCR amplification.

Theoretically, based on a haploid genome size of $3 \times 10^{9}$ bp, $1 \mu \mathrm{g}$ genomic DNA consists of $\sim 1.5 \times 10^{5}$ copies of each unique gene, derived as $6.23 \times 10^{23} \times\left(1 \times 10^{-6} \mathrm{~g}\right) /(330 \mathrm{~g} \times 2$ $\left.\times 3 \times 10^{9}\right)$. In the context of the 400 bp length of the $\mathrm{Vh}$ genes amplified here and an assumed PCR error rate of $1 / 2,000 \mathrm{bp}$, one out of every five amplified DNA molecules will have one PCR artifact after the first cycle of amplification. Assuming that PCR errors are random, then only one of every 6,000 first-amplified DNA molecules will contain an identical PCR artifact $([4-1] \times 400 \times 5)$. Therefore, the probability of sequencing two clones with the identical PCR artifact is extremely small. However, it remains possible that the characteristic nucleotides in the five potential new Vh genes in Baj are nonrandom PCR artifacts generated by unknown mechanisms similar to the reported restricted somatic mutation patterns (52).

It is noteworthy that, during the course of writing this report, we found that hv3005f 3 is identical to the M72 Vh cDNA sequence over a stretch of $291 \mathrm{bp}$, cloned very recently with a conventional method and reported by Schroeder and Wang (28). Similarly, hv3019b9 shares an identical stretch of $270 \mathrm{bp}$ with the 5A10 sequence isolated from a fetal liver-derived B cell line (Fig. 5; Jan Hillson, unpublished data). Thus, two of the five new Vh genes defined by PCR have already been confirmed independently by other investigators. Viewed as a whole, these data show that there are many hv3005- and 1.9IIIlike genes. These findings further support the concept that $\mathrm{Vh}$ gene repertoires in humans are quite heterogenous and complex, as demonstrated previously by RFLP analyses with conventional Ig Vh gene probes and designed oligomers $(38,40$, 48, 53-57).

By gene-counting experiments on Southern blot analyses and cloning, Honjo and associates first estimated that there were $18,6,26$, and $9 \mathrm{Vh}$ genes for $\mathrm{Vh} 1$ to $\mathrm{Vh} 4$ families, respectively (mentioned in reference 58). Subsequently, Alt and coworkers identified two new Vh gene families (i.e., Vh5 and Vh6) and suggested a total number of 300 or more Vh genes, including $\sim 125-150 \mathrm{Vh} 3$ genes (37). In addition, it was shown that $\mathrm{Vh}$ genes from different families are interspersed extensively, and that the single $\mathrm{Vh} 6$ gene and at least one $\mathrm{Vh}$ gene of the Vh5 family are most proximal to the heavy chain joining (Jh) gene locus $(37,47,59)$. Importantly, both Vh5 and Vh6 genes were found to be expressed preferentially during early ontogenic development $(27,28,60)$. However, the locations of the other developmentally regulated Vh genes (27), including the most frequently expressed 56P1-corresponding Vh gene, are presently unknown.

To explain the preferential expression of autoreactive $\mathrm{V}$ genes during early $B$ cell ontogeny, Coutinho and his colleagues proposed a "network" model $(31,61)$. They contended

Figure 5. Summary of seven highly homologous autoreactive $\mathrm{V}$ genes and some additional closely related $\mathrm{V}$ gene sequences. The complete nucleotide and amino acid sequences of Humhv3005 are given, while nucleotide sequences of others are given only at the positions where they differ from the hv3005 sequence. All sequences were first aligned for maximum homology, the nucleotides identical to hv3005 are indicated by bars, while the introduced gaps are marked by dots, which also indicate the unsequenced and/or unpublished regions in GL-SJ2 (36), M72 (28), and 5A10 (Hillson, J., unpublished data), as well as the intron in 56P1 (27). The CDRs and the conserved nucleotide sequences for splicing and rearrangement are marked. Three amino acid changes at amino acid positions 33, 52, and 98 are indicated. 
that, in the sterile fetal environment, stimulation by autoantigens and/or idiotype-antiidiotype interactions selectively expands the $B$ cells expressing the autoreactive $V$ genes to form an initial functional network. With maturation and exposure to exogenous antigens, the self-reactive $B$ cell pool diminishes in size, comprising only $\sim 20 \%$ of the adult B cell repertoire and interacting with the $80 \%$ of nonautoreactive resting B cells that are not connected to the network. With repeated exposure to conventional nonself antigens, the latter B cells respond, and, through somatic mutation, gene conversion, secondary gene rearrangement/replacement, and other diversification mechanisms, produce classical high affinity antibodies $(20,62$, 63). At the same time, the residual autoreactive $B$ cells interact with each other and with the nonconnected B cells, and thus maintain the homeostasis of the overall B cell repertoire.

In the context of this model, complete deletion of a cluster of developmentally important autoreactive $\mathrm{V}$ genes, such as hv3005-like genes, may lead to abnormal B cell development. This, in turn, may alter the humoral immune response to bacterial and/or viral infection, resulting in the overproduction of aberrant antibodies that contribute to the development and/or perpetuation of autoimmune disorders (29). Alternatively, deletion of hv3005-like genes may confer disease susceptibility through other mechanisms. For example, hv3005 is identical to the recently reported GL-SJ2 Vh gene which apparently encodes the heavy chain of RF-SJ2 (36). RFs have been shown to enhance ingestion of immune complexes by macrophages and clearance of these complexes, to stabilize weak antigen-antibody interactions, and to protect rats from neonatal Trypanosoma lewisi infection (reviewed in reference 64). In addition, it has been postulated that RFs may serve as the precursors for some antiidiotype antibodies $(65,66)$. Accordingly, deletion of hv3005-like genes may affect the regulated production of RFs and thus lead to abnormal immune responses to infectious microorganisms that result in autoimmune disorders. This paradigm is somewhat analogous to the postulate that C4A deficiency may interfere with normal clearance and solubilization of immune complexes and thereby induce SLE in many individuals with homozygous $\mathrm{C} 4 \mathrm{~A}$ null (reviewed in reference 67). Further studies are warranted to define precisely the underlying mechanisms for complete deletion of hv3005-like genes in autoimmune diseases.

In summary, sequence analyses of hv3005- and 1.9III-like genes in selected individuals show that, in most individuals, the hv3005-like genes reside in the 9.4-kb hv3005/P1 hybridizing band, while 1.9III-like genes reside in both 16- and 10-kb bands. Taken together with the previous RFLP study with hv3005/P1, these data provide evidence that homozygous deletion of certain autoreactive $\mathrm{V}$ gene(s) is associated with, and may predispose to, autoimmune disorders.

\section{Acknowledgments}

Funding for this research is supported in part by grants AR-39039, AR-33489, AR-25443, AR-07144, AR-40239, and RR-00833 from the National Institutes of Health, by grant MA10730 from the Medical Research Council of Canada, by grant 7-288-86 from the Arthritis Society of Canada, and by the Sam and Rose Stein Charitable Trust. Dr. Siminovitch is a Career Scientist of the Ontario Ministry of Health and a recipient of a Canadian Life and Health Insurance Association Medical Scholarship.

\section{References}

1. Theofilopoulos, A. N. 1987. Autoimmunity. In Basic and Clinical Immunology. D. P. Stites, J. D. Stobo, and J. W. Wells, editors. Appleton \& Lange. E. Norwalk, CN. 128-158.

2. Carson, D. A., P. P. Chen, R. I. Fox, T. J. Kipps, F. Jirik, R. D. Goldfien, G. Silverman, V. Radoux, and S. Fong. 1987. Rheumatoid factors and immune networks. Annu. Rev. Immunol. 5:109-126.

3. Zouali, M., B. D. Stollar, and R. S. Schwartz. 1988. Origin and diversification of anti-DNA antibodies. Immunol. Rev. 105:137-158.

4. Casali, P., and A. L. Notkins. 1989. Probing the human B-cell repertoire with EBV: polyreactive antibodies and CD5+ B lymphocytes. Annu. Rev. Immunol. 7:513-535.

5. Holmberg, D., A. A. Freitas, D. Portnoi, F. Jacquemart, S. Avrameas, and A. Coutinho. 1986. Antibody repertoires of normal BABL/c mice: B lymphocyte populations defined by state of activation. Immunol. Rev. 93:147-169.

6. Avrameas, S., B. Guilbert, W. Mahana, P. Matsiota, and T. Ternynck. 1988. Recognition of self and non-self constituents by polyspecific autoreceptors. Int. Rev. Immunol. 3:1-15.

7. Chen, P. P., S. Fong, F. Goni, G. J. Silverman, R. I. Fox, M.-F. Liu, B. Frangione, and D. A. Carson. 1988. Cross-reacting idiotypes on cryoprecipitating rheumatoid factor. Springer Semin. Immunopathol. 10:35-55.

8. Dersimonian, H., R. S. Schwartz, K. J. Barrett, and B. D. Stollar. 1987. Relationship of human variable region heavy chain germ-line genes to genes encoding anti-DNA autoantibodies. J. Immunol. 139:2496-2501.

9. Chen, P. P., M. Liu, S. Sinha, and D. A. Carson. 1988. A 16/6 idiotype positive anti-DNA antibody is encoded by a conserved Vh gene with no somatic mutation. Arthritis Rheum. 31:1429-1431.

10. Sanz, I., H. Dang, M. Takei, N. Talal, and J. D. Capra. 1989. V-H sequence of a human anti-Sm autoantibody. J. Immunol. 142:883-887.

11. Cairns, E., P. C. Kwong, V. Misener, P. Ip, D. A. Bell, and K. A. Siminovitch. 1989. Analysis of variable region genes encoding a human anti-DNA antibody of normal origin: implications for the molecular basis of human autoimmune responses. J. Immunol. 143:685-691.

12. Siminovitch, K. A., V. Misener, P. C. Kwong, Q.-L. Song, and P. P. Chen. 1989. A natural autoantibody is encoded by germline heavy and lambda light chain variable region genes without somatic mutation. J. Clin. Invest. 84:16751678 .

13. Logtenberg, T., F. M. Young, J. H. Van Es, F. H. J. Gmelig-Meyling, and F. W. Alt. 1989. Autoantibodies encoded by the most Jh-proximal human immunoglobulin heavy chain variable region gene. J. Exp. Med. 170:1347-1355.

14. Naparstek, Y., J. Andre-Schwartz, T. Manser, L. J. Wysocki, L. Breitman, B. D. Stollar, M. Gefter, and R. S. Schwartz. 1986. A single germline VH gene segment of normal $\mathrm{A} / \mathrm{J}$ mice encodes autoantibodies characteristic of systemic lupus erythematosus. J. Exp. Med. 164:614-626.

15. Reininger, L., P. Ollier, P. Poncet, A. Kaushik, and J.-C. Jaton. 1987 Novel $\mathrm{V}$ genes encode virtually identical variable regions of six murine monoclonal anti-bromelain-treated red blood cell autoantibodies. J. Immunol. 138:316323.

16. Hardy, R. R., C. E. Carmack, S. A. Shinton, R. J. Riblet, and K. Hayakawa. 1989. A single VH gene is utilized predominantly in anti-BrMRBC hybridomas derived from purified Ly-1 B cells. Definition of the VH11 family. J. Immunol. 142:3643-3651.

17. Dighiero, G., P. Lymberi, D. Holmberg, I. Lundquist, A. Coutinho, and S. Avrameas. 1985. High frequency of natural autoantibodies in normal newborn mice. J. Immunol. 134:765-771.

18. Glotz, D., M. Sollazzo, S. Riley, and M. Zanetti. 1988. Isotype, VH genes, and antigen-binding analysis of hybridomas from newborn normal BALB/c mice. J. Immunol. 141:383-390.

19. Souroujon, M., M. E. White-Scharf, J. Andre-Schwartz, M. L. Gefter, and R. S. Schwartz. 1988. Preferential autoantibody reactivity of the preimmune B cell repertoire in normal mice. J. Immunol. 140:4173-4179.

20. Alt, F. W., T. K. Blackwell, and G. D. Yancopoulos. 1987. Development of the primary antibody repertoire. Science (Wash. DC). 238:1079-1087.

21. Perlmutter, R. M. 1987. Programmed development of the antibody repertoire. Curr. Top. Microbiol. Immunol. 135:96-109.

22. Yancopoulos, G. D., B. A. Malynn, and F. W. Alt. 1988. Developmentally regulated and strain-specific expression of murine VH gene families. J. Exp. Med. 168:417-435.

23. Monestier, M., A. Manheimer-Lory, B. Bellon, C. Painter, H. Dang, N. Talal, M. Zanetti, R. Schwartz, D. Pisetsky, R. Kuppers, N. Rose, J. Brochier, L. Klareskog, R. Holmdahl, B. Erlanger, F. Alt, and C. Bona. 1986. Shared idiotopes and restricted immunoglobulin variable region heavy chain genes characterize murine auto-antibodies of various specificities. J. Clin. Invest. 78:753-759.

24. Holmberg, D. 1987. High connectivity, natural antibodies preferentially use 7183 and QUPC 52 Vh families. Eur. J. Immunol. 17:399-403.

25. Bona, C. A. 1988. V genes encoding autoantibodies: molecular and phenotypic characteristics. Annu. Rev. Immunol. 6:327-358. 
26. Sollazzo, M., C. A. Hasemann, K. D. Meek, D. Goltz, J. D. Capra, and M Zanetti. 1989. Molecular characterization of the V-H region of murine autoantibodies from neonatal and adult BALB/c mice. Eur. J. Immunol. 19:453-457.

27. Schroeder, Jr., H. W., J. L. Hillson, and R. M. Perlmutter. 1987. Early restriction of the human antibody repertoire. Science (Wash. DC). 238:791-793

28. Schroeder, Jr., H. W., and J. Y. Wang. 1990. Preferential utilization of conserved immunoglobulin heavy chain variable gene segments during human fetal life. Proc. Natl. Acad. Sci. USA. 87:6146-6150.

29. Chen, P. P., N. J. Olsen, P.-M. Yang, R. W. Soto-Gil, T. Olee, K. A. Siminovitch, and D. A. Carson. 1990. From human autoantibodies to fetal antibody repertoire to B cell malignancy: it's a small world after all. Int. Rev. Im munol. 5:239-251.

30. Siminovitch, K. A., and P. P. Chen. 1990. The biologic significance of human natural autoimmune responses: relationship to the germline, early immune and malignant B cell variable gene repertoire. Intern. Rev. Immunol. 5:265-277.

31. Coutinho, A., A. Grandien, J. Faro-Rivas, and T. A. Mota-Santos. 1988 Idiotypes, tailors and networks. Ann. Inst. Pasteur Immunol. 139:599-607.

32. Vakil, M., and J. F. Kearney. 1986. Functional characterization of monoclonal auto-antidiotype antibodies isolated from the early B cell repertoire of BALB/c mice. Eur. J. Immunol. 16:1151-1158.

33. Kearney, J. F., N. Solvason, A. Bloem, and M. Vakil. 1990. Idiotypes and B cell development. In Idiotypes in Biology and Medicine. D. A. Carson, P. P. Chen, and T. J. Kipps, editors. Karger, Basel. 1-13.

34. Chen, P. P. 1990. Structural analyses of human developmentally regulated Vh3 genes. Scand. J. Immunol. 32:257-267.

35. Crowley, J. J., R. A. Mageed, G. J. Silverman, P. P. Chen, F. Kozin, R. A. Erger, R. Jefferis, and D. A. Carson. 1990. The incidence of a new human crossreactive idiotype linked to subgroup $\mathrm{V}_{\mathbf{H}}$ III heavy chains. Mol. Immunol. 27:8794.

36. Pascual, V., I. Randen, K. Thompson, M. Sioud, O. Forre, J. Natvig, and J. D. Capra. 1990. The complete nucleotide sequences of the heavy chain variable regions of six monospecific rheumatoid factors derived from Epstein-Barr virustransformed B cells isolated from the synovial tissue of patients with rheumatoid arthritis. J. Clin. Invest. 86:1320-1328.

37. Berman, J. E., S. J. Mellis, R. Pollock, C. L. Smith, H. Suh, B. Heinke, C. Kowal, U. Surti, L. Chess, C. R. Cantor, and F. W. Alt. 1988. Content and organization of the human Ig VH locus: definition of three new VH families and linkage to the Ig CH locus. EMBO (Eur. Mol. Biol. Organ.) J. 7:727-738.

38. Yang, P.-M., N. J. Olsen, K. A. Siminovitch, T. Olee, F. Kozin, D. A. Carson, and P. P. Chen. 1990. Possible deletion of a developmentally regulated Vh gene in autoimmune disease. Proc. Natl. Acad. Sci. USA. 87:7907-7911.

39. Saiki, R. K., D. H. Gelfand, S. Stoffel, S. J. Scharf, R. Higuchi, G. T. Horn, K. B. Mullis, and H. A. Erlich. 1988. Primer-directed enzymatic amplification of DNA with a thermostable DNA polymerase. Science (Wash. DC). 239:487-491.

40. Chen, P. P., K. A. Siminovitch, N. J. Olsen, R. A. Erger, and D. A. Carson. 1989. A highly informative probe for two polymorphic $\mathrm{Vh}$ gene regions which contain one or more autoantibody-associated Vh genes. J. Clin. Invest. 84:706710 .

41. Messing, J. 1983. New M13 vectors for cloning. Methods Enzymol. 101:20-78.

42. Maniatis, T, E. F. Fritsch, and J. Sambrook. 1982. Molecular Cloning: A Laboratory Manual. Cold Spring Harbor Laboratory, Cold Spring Harbor, NY. 43. Wallace, R. B., and C. G. Miyada. 1987. Oligonucleotide probes for the screening of recombinant DNA libraries. Methods Enzymol. 152:432-442.

44. Devereux, J., P. Haeberli, and O. Smithies. 1984. A comprehensive set of sequence analysis programs for the VAX. Nucleic Acids Res. 12:387-395.

45. Matthyssens, G., and T. H. Rabbitts. 1980. Structure and multiplicity of genes for the human immunoglobulin heavy chain variable region. Proc. Natl. Acad. Sci. USA. 77:6561-6565.

46. Rechavi, G., D. Ram, L. Glazer, R. Zakut, and D. Givol. 1983. Evolution- ary aspects of immunoglobulin heavy chain variable region (VH) gene subgroups. Proc. Natl. Acad. Sci. USA. 80:855-859.

47. Kodaira, M., T. Kinashi, I. Umemura, F. Matsuda, T. Noma, Y. Ono, and T. Honjo. 1986. Organization and evolution of variable region genes of the human immunoglobulin heavy chain. J. Mol. Biol. 190:529-541.

48. Van Dijk, K. W., H. W. Schroeder Jr., R. M. Perlmutter, and E. C. B. Milner. 1989. Heterogeneity in the human immunoglobulin V-H locus. J. Immunol. 142:2547-2554.

49. Shuldiner, A. R., A. Nirula, and J. Roth. 1989. Hybrid DNA artifact from PCR of closely related target sequences. Nucleic Acids Res. 17:4409-4409.

50. Innis, M. A., K. B. Myambo, D. H. Gelfand, and M. A. D. Brow. 1988. DNA sequencing with Thermus aquaticus DNA polymerase and direct sequencing of polymerase chain reaction-amplified DNA. Proc. Natl. Acad. Sci. USA 85:9436-9440.

51. Carroll, W. L., M. Yu, M. P. Link, and S. J. Korsmeyer. 1989. Absence of Ig $\mathrm{V}$ region gene somatic hypermutation in advanced Burkitt's lymphoma. $J$. Immunol. 143:692-698.

52. Levy, S., E. Mendel, S. Kon, Z. Avnur, and R. Levy. 1988. Mutational hot spots in Ig V region genes of human follicular lymphomas. J. Exp. Med. 168:475489.

53. Johnson, M. J., A. M. Natali, H. M. Cann, T. Honjo, and L. L. CavalliSforza. 1984. Polymorphisms of a human variable heavy chain gene show linkage with constant heavy chain genes. Proc. Natl. Acad. Sci. USA. 81:7840-7844.

54. Walter, M. A., and D. W. Cox. 1988. Analysis of genetic variation reveals human immunoglobulin VH-region gene organization. Am. J. Hum. Genet. 42:446-451.

55. Souroujon, M. C., D. B. Rubinstein, R. S. Schwartz, and K. J. Barrett. 1989. Polymorphisms in human $\mathrm{H}$ chain $\mathrm{V}$ region genes from the V-HIII gene family. J. Immunol. 143:706-711.

56. Guillaume, T., D. B. Rubinstein, F. Young, L. Tucker, T. Logtenberg, R. S. Schwartz, and K. J. Barrett. 1990. Individual Vh genes detected with oligonucleotide probes from the complementarity-determining regions. J. Immunol. 145:1934-1945.

57. Sasso, E. H., K. W. Van Dijk, and E. C. B. Milner. 1990. Prevalence and polymorphism of human VH3 genes. J. Immunol. 145:2751-2757.

58. Lee, K. H., F. Matsuda, T. Kinashi, M. Kodaira, and T. Honjo. 1987. A novel family of variable region genes of the human immunoglobulin heavy chain J. Mol. Biol. 195:761-768.

59. Humphries, C. G., A. Shen, W. A. Kuziel, J. D. Capra, F. R. Blattner, and P. W. Tucker. 1988. A new human immunoglobulin VH family preferentially rearranged in immature B-cell tumors. Nature (Lond.). 331:446-449.

60. Cuisinier, A.-M., V. Guigou, L. Boubli, M. Fougereau, and C. Tonnelle 1989. Preferential expression of $V_{H} 5$ and $V_{H} 6$ immunoglobulin genes in early human B-cell ontogeny. Scand. J. Immunol. 30:493-497.

61. Coutinho, A. 1989. Beyond clonal selection and network. Immunol. Rev. 110:63-87.

62. French, D. L., R. Laskov, and M. D. Scharff. 1989. The role of somatic hypermutation in the generation of antibody diversity. Science (Wash.). 244:1152-1157.

63. Wysocki, L. J., and M. L. Gefter. 1989. Gene conversion and the generation of antibody diversity. Annu. Rev. Biochem. 58:509-531.

64. Chen, P. P., S. Fong, and D. A. Carson. 1987. Rheumatoid factor. Rheum. Dis. Clin. North Am. 13:545-568.

65. Chen, P. P., S. Fong, R. A. Houghten, and D. A. Carson. 1985. Characterization of an epibody: an antiidiotype which reacts with both the idiotype of rheumatoid factors (RF) and the antigen recognized by RF. J. Exp. Med. 161:323-331.

66. Chen, P. P., S. Fong, and D. A. Carson. 1988. Molecular basis of reactivity of epibodies. In Biological Applications of Anti-Idiotypes. C. A. Bona, editor. CRC Press Inc., Boca Raton, FL. Vol. 1. 41 pp.

67. Steinberg, A. D., and D. M. Klinman. 1988. Pathogenesis of systemic lupus erythematosus. Rheum. Dis. Clin. North Am. 14:25-41. 